\title{
Effect of DNA Methylation in Various Diseases and the Probable Protective Role of Nutrition: A Mini-Review
}

\author{
Venkataramana Kandi $^{1}$, Sabitha Vadakedath ${ }^{2}$ \\ 1. Microbiology, Prathima Institute of Medical Sciences, Karimnagar, IND 2. Biochemistry, Prathima \\ Institute of Medical Sciences, Karimnagar, IND
}

$\square$ Corresponding author: Venkataramana Kandi, ramana20021@gmail.com

Disclosures can be found in Additional Information at the end of the article

\section{Abstract}

DNA methylation, a process of adding a methyl group to DNA done by a DNA methyltransferase is a heritable (epigenetic) alteration leading to cancer, atherosclerosis, nervous disorders (Imprinting disorders), and cardiovascular diseases. The role of nutrition in DNA methylation is revealed by identification of methyl variable positions (MVP) on DNA. These regions are more susceptible to DNA methylations. Nutritional supplementation of folic acid and methionine in utero and in adults decreased epigenetic modifications due to its role in DNA metabolism (one carbon metabolism). Thus, in utero and adult supplementation of folic acid and methionine may reduce DNA methylation. This review attempts to highlight the process of DNA methylation, its effect on various diseases, and the probable protective role of nutrition.

Categories: Genetics, Pathology

Keywords: dna methylation, epigenetic modifications, imprinting disorders, methyltransferase

\section{Introduction And Background}

DNA methylation is a genetic process that is extensively being researched among mammals, including humans. The epigenetic modifications in DNA contribute to the regulation of gene expression. DNA methylation is associated with histone modifications, which play a key role in regulating the functioning of the DNA by altering chromatin structure. The information imprinted on the genes is epigenetically marked during gametogenesis and is expressed/transferred to the offspring's familially. The process of genetic transfer may be influenced by a phenomenon called as DNA methylation. The significance of DNA methylation and its role in the development of various diseases/processes that include formation of tumours, atherosclerosis, cardiovascular diseases, imprinting disorders, and ageing is least understood. Considering the fact that DNA methylation is a reversible process, we have attempted to highlight the effect of DNA methylation in various diseases and the beneficial role of nutrition in this mini review. The process of addition of the methyl group to DNA is DNA methylation. The major donor of the methyl group is s-adenosylmethionine (SAM) formed from methionine, and the methylation reaction is done by the action of the enzyme DNA methyltransferase (DMT) as shown in Figure 1 [1].

Kandi et al. This is an open access article distributed under the terms of the Creative Commons Attribution License CC-BY 3.0., which permits unrestricted use, distribution, and reproduction in any medium, provided the original author and source are credited.
Received 08/11/2015

Review began 08/12/2015

Review ended 08/15/2015

Published 08/24/2015
How to cite this article

Kandi V, Vadakedath S (August 24, 2015) Effect of DNA Methylation in Various Diseases and the Probable Protective Role of Nutrition: A Mini-Review. Cureus 7(8): e309. DOI 10.7759/cureus.309 


\section{Cureus}

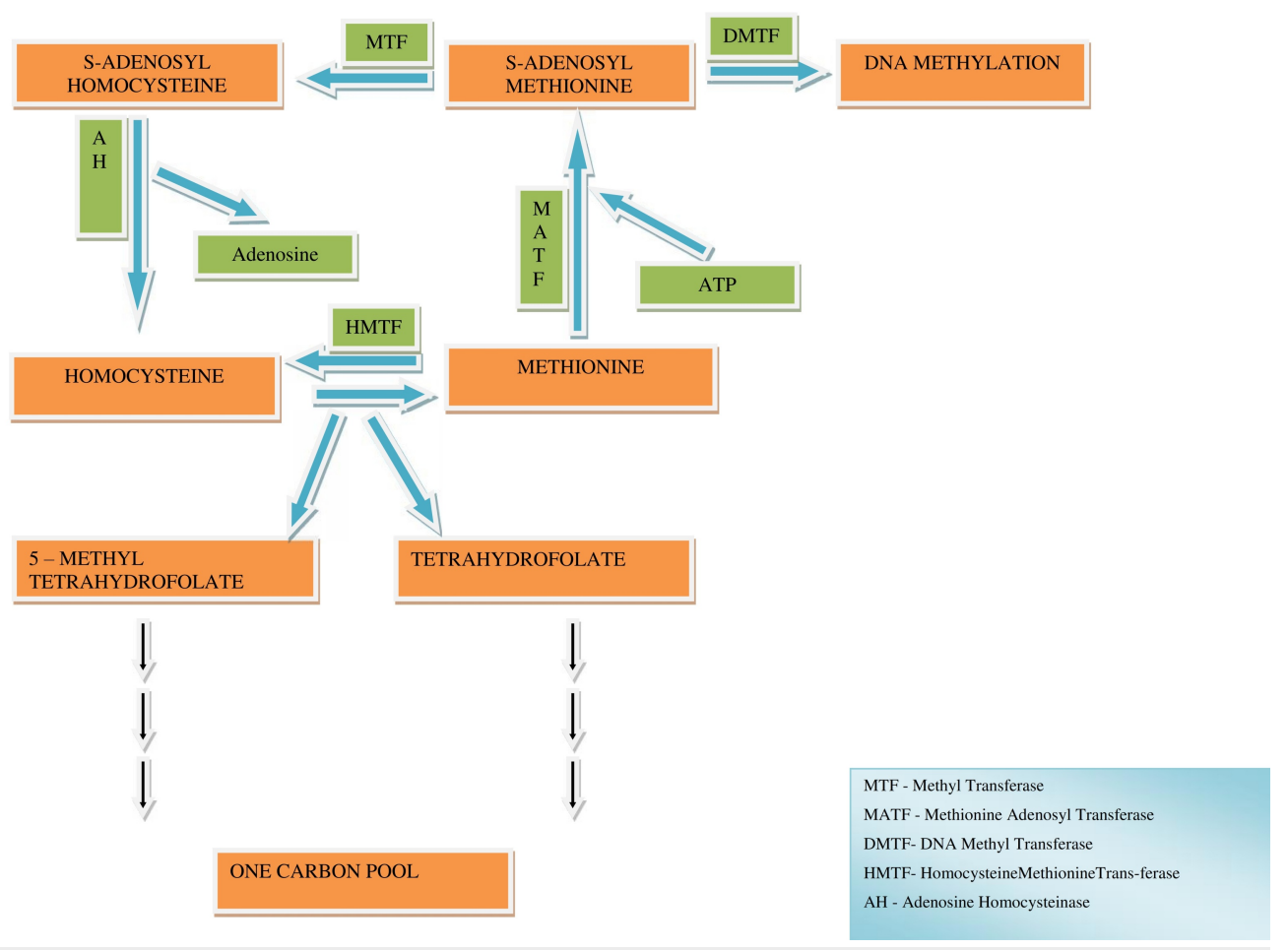

FIGURE 1: Reactions contributing to DNA methylation

The methyl group is accepted by either adenine or cytosine of DNA. Adenine methylation is predominant in prokaryotes, whereas cytosine methylation is dominant in eukaryotes with variability in different species [2].

\section{Review}

\section{DNA methyltransferase (DMTF)}

DNA methyltransferase (DMTF) is an enzyme involved in methylating cytosine/adenine residues of DNA. There are two types of DMTF: the maintenance DMTF and the de novo DMTF [3]. Maintenance DMTF helps in copying methylated patterns of parent strands to the daughter strand during the replication process. De novo DMTF helps in creating new methylated patterns to DNA during development [4]. In stem cells, the non-methylated regions of DNA are lost during cell differentiation and are a specific feature of stem cells when compared with fibroblasts. Aberrant DNA methylation might contribute to decreased transcriptional activity of some genes involved in stem cell maintenance and differentiation. Thus, methylated/nonmethylated DNA pattern transmission depends completely on their location within the gene [5].

\section{Effects of DNA methylation}

DNA methylation is an epigenetic modification, i.e., heritable change in DNA without any modifications to the sequence of DNA. It alters expression of a gene during cell differentiation and causes a change that is heritable. Methylated modifications of DNA occur during the mitotic or meiotic division of the cell [6]. Methylated DNA usually represses transcription of a gene and these methylated DNA are not recognized by RNA polymerases; thus, it becomes one of the mechanisms to control gene expression [7]. DNA methylation in turn regulates the 
expression of enzymes, like histone deacetylase, resulting in the modification of chromatin structure [8].

DNA methylation changes are associated with a number of diseases such as imprinting disorders [9], cardiovascular diseases [10], autoimmune diseases, neurological disorders [11], and cancer [12]. The advantages of DNA methylation in humans include regulation of longterm storage of memory, which can be used to estimate age, and biological clocks in humans [13-15]. DNA can be demethylated by the base-excision repair system.

\section{Cancer}

In general, altered DNA methylation is an important factor associated with cancer development. Hypermethylation in an abnormal state leads to transcriptional silencing and gene inactivation, whereas hypomethylation is linked to chromosomal instability and loss of imprinting (transfer of methylated patterns to daughter cells). Thus, DNA methylation can cause hypermethylation of tumor suppressor genes (oncogene suppressor) and hypomethylation of oncogenes [16-17].

\section{Imprinting disorders}

The process of expressing the DNA methylation pattern of a specific gene based on parental origin is known as imprinting [18]. The failure of this process of imprinting leads to imprinting disorders. Angelman's syndrome is an imprinted neurodevelopmental disorder caused due to the deficiency of maternal ubiquitin ligase enzyme. Prader-Willi syndrome is also an imprinting neurobehavourial disorder due to the deficiency of ubiquitin ligase enzyme of paternal origin. Thus, loss of the maternal/paternal imprinting centre leads to abnormal DNA methylations, which could lead to epigenetic modification in DNA [19-20]. Loss of imprinting not only in DNA methylation but also in the binding protein involved in methylation also contributes to imprinting disorders.

\section{Aging}

DNA methylation is suppressed during zygote formation and enhanced methylation is seen during development. There is a loss of DNA methylation during aging [21]. Biological clocks act as biomarkers for predicting the process of aging [22]. With the advancement in age, the genes, such as estrogen receptor, insulin-like growth factor 2 (IGF2), $\mathrm{p}^{16}$, etc., get hypermethylated, and there is abnormal DNA methylation leading to a heritable change.

\section{Atherosclerosis}

DNA methylation polymorphism forms an important biomarker for atherosclerosis. Monocytes and lymphocytes are the sites for DNA methylation polymorphism [23-25] (Figure 2). 


\section{Cureus}

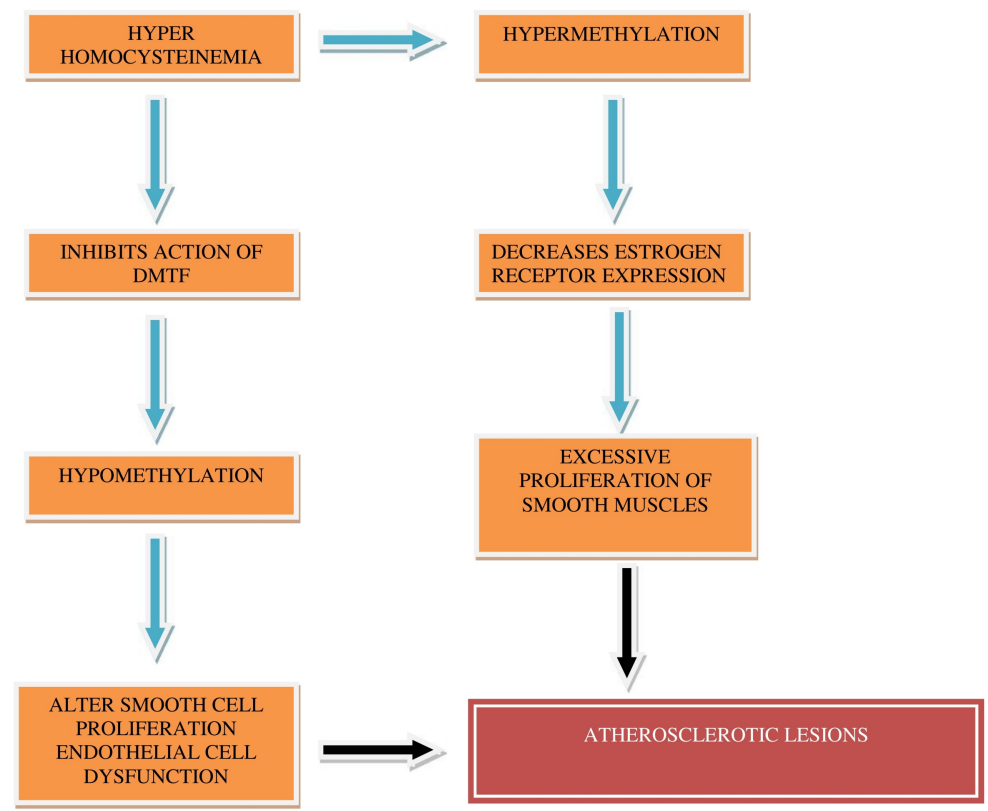

\section{FIGURE 2: Flow chart showing various causes of hyper/hypo methylation of DNA leading to Atherosclerotic lesions}

Thus, either hypo- or hypermethylation leads to altered smooth muscle cell proliferation contributing to atherosclerotic lesions. Hypomethylation of monocytes and lymphocytes and hypermethylation of gene-specific areas takes place. Atherosclerosis, if untreated, leads to cardiovascular disease.

\section{Nutrition: Its role in DNA methylation}

Nutrition plays an important role in health, disease conditions, and influences in utero development. There are areas on DNA, which are sensitive to methylation based on few previous studies on nutrition, and these regions are identified as methylation variable positions (MVP). The observation of MVPs explains the role of nutrition in the fetal origin of adult diseases. There are several theories put forward to explain the fetal origin of adult diseases. These theories describe that nutrition plays an important role on adult disease risk and its transfer to the offspring [26]. It also predicts that fetal growth impairment is associated with adult cardiovascular disease, diabetes, and insulin resistance [27-28]. A previous study has revealed that prenatal and early post-natal exposure to famine may increase the risk of obesity [29], schizophrenia, lung diseases, and even breast cancer in women [30].

But in humans, folic acid and methionine play an important role in DNA modifications. As we know that folic acid functions as a one-carbon metabolism that supplies carbon for purine and pyrimidine synthesis, it becomes important to have a good understanding of its role in DNA modifications both in utero and in adults. Periconceptional supplementation of folic acid increased DNA methylation by $4.5 \%$ of IGF2 [31]. Along with methyl supplementation, the folic acid requirement is very much necessary for postmenopausal women not only for proper 
nervous system functions but also for preventing epigenetic alterations [32]. In a study, cord blood sample analysis revealed that folic acid status is inversely related to homocysteine and vice-versa [33]. DNA methylation of 12 genes (EIF2C3, ZBTB11, BDH2, ZNF187, RUNX1T1, C9 or f64, PDE2A, MGC33486, AMN, ZPBP2, FBN3, and PVRL2) directly correlated to homocysteine levels and methylation of five genes (ATP5F1, CYP26C1, FSTL3, MDS032, and BMX) showed an inverse correlation with homocysteine levels [34]. Thus, nutrient-based DNA methylation is gene specific, site specific, tissue specific, and age specific.

\section{Conclusions}

DNA methylation can lead to an epigenetic change, as it regulates gene expression by controlling the transcription of the concerned genes. Folic acid and methionine play a significant role in restraining DNA methylation; in utero and adult supplementation of these nutrients can prevent tumorigenesis and harmful effects of DNA methylation. Further research should concentrate on the usefulness of therapeutic interventions in minimizing the adverse effects of DNA methylation.

\section{Additional Information}

\section{Disclosures}

Conflicts of interest: In compliance with the ICMJE uniform disclosure form, all authors declare the following: Payment/services info: All authors have declared that no financial support was received from any organization for the submitted work. Financial relationships: All authors have declared that they have no financial relationships at present or within the previous three years with any organizations that might have an interest in the submitted work. Other relationships: All authors have declared that there are no other relationships or activities that could appear to have influenced the submitted work.

\section{References}

1. Richardson B: DNA methylation and autoimmune disease. Clin Imunol. 2003, 109:72-79. 10.1016/S1521-6616(03)00206-7

2. Capuano F, Mulleder M, Kok RM, Blom HJ, Ralser M: Cytosine DNA methylation is found in Drosophila melanogaster but absent in Saccharomyces cerevisiae, Schizosaccharomyces pombe and other yeast species. Analytical chemistry. Anal Chem. 2014, 86:3697-702. 10.1021/ac500447w

3. Review on DNA Methylation. (2008). Accessed: August 10, 2015: http://www.methods.info/Methods/DNA_methylation/Methylation_review.html.

4. Goll MG, Kirpekar F, Maggert KA, Yoder JA, Hsieh CL, Zhang X, Golic KG, Jacobsen SE, Bestor TH: Methylation of tRNAAsp by the DNA methyltransferase homolog Dnmt2 . Science. 2006, 311:395-98. 10.1126/science.1120976

5. Gonzalgo ML, Liang G, Spruck CH 3rd, Zingg JM, Rideout WM 3rd, Jones PA: Identification and characterization of differentially methylated regions of genomic DNA by methylationsensitive arbitrarily primed PCR. Cancer Res. 1997, 57:594-99.

6. Lister R, Pelizzola M, Dowen RH, Hawkins RD, Hon G, Tonti-Filippini J, Nery JR, Lee L, Ye Z, Ngo QM, Edsall L, Antosiewicz-Bourget J, Stewart R, Ruotti V, Millar AH, Thomson JA, Ren B, Ecker JR: Human DNA methylomes at base resolution show widespread epigenomic differences. Nature. 2009, 462:315-22. 10.1038/nature08514

7. Klose RJ, Bird AP: Genomic DNA methylation: the mark and its mediators . Trends Biochem Sci. 2006, 31:89-97. 10.1016/j.tibs.2005.12.008

8. Choy MK, Movassagh M, Goh HG, Bennett MR, Down TA, Foo RS: Genome-wide conserved consensus transcription factor binding motifs are hyper-methylated. BMC Genomics. 2010, 11:519. 10.1186/1471-2164-11-519

9. Paulsen M, Ferguson-Smith AC: DNA methylation in genomic imprinting, development, and disease. J Pathol. 2001, 195:97-110. 10.1002/path.890

10. Kim M, Long TI, Arakawa K, Wang R, Yu MC, Laird PW: DNA methylation as a biomarker for 
cardiovascular disease risk. PLoS One. 2010, 5:e9692. 10.1371/journal.pone.0009692

11. Urdinguio RG, Sanchez-Mut JV, Esteller M: Epigenetic mechanisms in neurological diseases: genes, syndromes, and therapies. Lancet Neurol. 2009, 8:1056-72. 10.1016/S14744422(09)70262-5

12. Esteller M: Aberrant DNA methylation as a cancer-inducing mechanism . Annu Rev Pharmacol Toxicol. 2005, 45:629-56. 10.1146/annurev.pharmtox.45.120403.095832

13. Miller CA, Sweatt JD: Covalent modification of DNA regulates memory formation . Neuron. 2007, 53:857-69. 10.1016/j.neuron.2007.02.022

14. Powell D: Memories may be stored on your DNA . New Scientist. 2008, 200:12. Accessed: August 10, 2015: https://www.newscientist.com/article/mg20026845-000-memories-may-bestored-on-your-dna/. 10.1016/S0262-4079(08)62993-0

15. Horvath S: DNA methylation age of human tissues and cell types. Genome Biol. 2013, 14:R115. 10.1186/gb-2013-14-10-r115

16. Zhang FF, Cardarelli R, Carroll J, Zhang S, Fulda KG, Gonzalez K, Vishwanatha JK, Morabia A, Santella RM: Physical activity and global genomic DNA methylation in a cancer-free population. Epigenetics. 2011, 6:293-99. 10.4161/epi.6.3.14378

17. Kulis M, Esteller M: DNA methylation and cancer. Adv Genet. 2011, 70:27-56. 10.1016/B9780-12-380866-0.60002-2

18. Kaneda M, Okano M, Hata K, Sado T, Tsujimoto N, Li E, Sasaki H: Essential role for de novo DNA methyltransferase Dnmt3a in paternal and maternal imprinting. Nature. 2004, 429:9003. 10.1038/nature02633

19. White HE, Durston VJ, Harvey JF, Cross NC: Quantitative analysis of SNRPN(correction of SRNPN) gene methylation by pyrosequencing as a diagnostic test for Prader-Willi syndrome and Angelman syndrome. Clin Chem. 2006, 52:1005-13. 10.1373/clinchem.2005.065086

20. Horsthemke B, Wagstaff J: Mechanisms of imprinting of the Prader-Willi/Angelman region. Am J Med Genet A. 2008, 146A:2041-52. 10.1002/ajmg.a.32364

21. Gonzalo S: Epigenetic alterations in aging. J Appl Physiol. 2010, 109:586-597. 10.1152/japplphysiol.00238.2010

22. Jones MJ, Goodman SJ, Kobor MS: DNA methylation and healthy human aging. Aging Cell. 2015, 10.1111/acel.12349

23. Lund G, Andersson L, Lauria M, Lindholm M, Fraga MF, Villar-Garea A, Ballestar E, Esteller M, Zaina S: DNA methylation polymorphisms precede any histological sign of atherosclerosis in mice lacking apolipoprotein E. J Biol Chem. 2004, 279:29147-54. 10.1074/jbc.M403618200

24. Castro R, Rivera I, Struys EA, Jansen EE, Ravasco P, Camilo ME, Blom HJ, Jakobs C, Tavares de Almeida I: Increased homocysteine and S-adenosylhomocysteine concentrations and DNA hypomethylation in vascular disease. Clin Chem. 2003, 49:1292-96. 10.1373/49.8.1292

25. Huang YS, Zhi YF, Wang SR: Hypermethylation of estrogen receptor-alpha gene in atheromatosis patients and its correlation with homocysteine. Pathophysiology. 2009, 16:25965. 10.1016/j.pathophys.2009.02.010

26. Barker DJ: The fetal and infant origins of adult disease . BMJ. 1990, 301:1111. 10.1136/bmj.301.6761.1111

27. Barker DJ: Fetal nutrition and cardiovascular disease in later life . Br Med Bull. 1997, 53:96108. 10.1093/oxfordjournals.bmb.a011609

28. Barker DJ: The fetal origins of type 2 diabetes mellitus . Ann Intern Med. 1999, 130:322-24. 10.7326/0003-4819-130-4-199902160-00019

29. Ravelli GP, Stein ZA, Susser MW: Obesity in young men after famine exposure in utero and early infancy. NEJM. 1976, 295:349-53. 10.1056/NEJM197608122950701

30. Roseboom T, de Rooij S, Painter R: The Dutch famine and its long-term consequences for adult health. Early Hum Dev. 2006, 82:485-91. 10.1016/j.earlhumdev.2006.07.001

31. Steegers-Theunissen RP, Obermann-Borst SA, Kremer D, Lindemans J, Siebel C, Steegers EA, Slagboom PE, Heijmans BT: Periconceptional maternal folic acid use of 400 microg per day is related to increased methylation of the IGF2 gene in the very young child. PLoS One. 2009, 4:e7845. 10.1371/journal.pone.0007845

32. Rampersaud GC, Kauwell GP, Hutson AD, Cerda JJ, Bailey LB: Genomic DNA methylation decreases in response to moderate folate depletion in elderly women. Am J Clin Nutr. 2000, 72:998-1003.

33. Fryer AA, Emes RD, Ismail KM, Haworth KE, Mein C, Carroll WD, Farrell WE: Quantitative, high-resolution epigenetic profiling of $\mathrm{CpG}$ loci identifies associations with cord blood 


\section{Cureus}

plasma homocysteine and birth weight in humans. Epigenetics. 2011, 6:86-94.

10.4161/epi.6.1.13392

34. Deaton AM, Bird A: CpG islands and the regulation of transcription . Genes Dev. 2011, 25:1010-22. 10.1101/gad.2037511 